\title{
Mandibular Inferior Cortex Erosion on Dental Panoramic Radiograph as a Sign of Low Bone Mineral Density in Postmenopausal Women
}

\section{Erosão do córtex mandibular inferior em radiografias maxilares panorâmicas como sinal de osteoporose em mulheres na pós-menopausa}

\author{
Juliana Zigart Brum Carmo ${ }^{1}$ Sebastião Freitas de Medeiros ${ }^{1}$ \\ ${ }^{1}$ Department of Obstetrics and Gynecology, Hospital Universitário \\ Júlio Müller, Faculdade de Medicina, Universidade Federal de Mato \\ Grosso, Cuiabá, MT, Brazil \\ Rev Bras Ginecol Obstet 2017;39:663-669. \\ Address for correspondence Juliana Zigart Brum Carmo, \\ Departmento de Ginecologia e Obstetrícia, Hospital Universitário \\ Júlio Müller, Faculdade de Medicina, Universidade Federal de Mato \\ Grosso, Av Marechal Deodoro, 1150, Ap 401, Cuiabá-MT, \\ 78005-100, Brazil (e-mail: juliazgt@gmail.com).
}

\begin{abstract}
Objective To examine the role of the panoramic mandibular radiograph in the diagnosis of low bone mineral density (BMD) in postmenopausal women.

Methods A cross-sectional study including volunteer women aged over 40 years in amenorrhea due to ovarian failure for at least 12 months, who were cared for at the climacteric outpatient clinic of a university hospital in the city of Cuiabá, in the state of Mato Grosso, Brazil. The panoramic radiographs were evaluated using a specific software. Two aspects were analyzed in the mandibular panoramic radiograph: a qualitative aspect regarding the shape of the mandibular cortical bone, and a quantitative aspect regarding the width of the mandibular cortical bone. The morphology of the mandibular cortical bone in the digital panoramic radiograph was determined bilaterally by the observation of the bone structure between the mental foramen and the base of the jaw. The mandibular cortical bone was categorized into three groups. The mental index (MI) was used to evaluate the thickness of the mandibular cortical bone through a perpendicular line drawn from the base of the mandible at the height of the center of the mental foramen, with another line drawn tangent to the inferior border of the mandible, and a third line parallel to the line at the superior border of the mandible. The MI data are expressed in millimeters, with a normal value of $3.0 \mathrm{~mm}$. The densities of the lumbar spine and femur, expressed in $\mathrm{g} / \mathrm{cm}^{2}$, were categorized as normal, osteopenia or osteoporosis.

Keywords

- osteoporosis

- climacteric

- mandible

- panoramic radiograph

- menopause

Results The agreement index between the MI and the BMD of the lumbar spine was good (Kappa $=0.718$ ), but the same index between the MI and the BMD of the femoral neck was poor (Kappa $=0.443)$. An excellent agreement occurred when the mandibular cortical index $(\mathrm{MCl})$ was compared with the BMD of the lumbar spine (Kappa $=0.912$ ). The agreement between $\mathrm{MCl}$ and the BMD in the femur was moderated $($ Карpa $=0.579)$.
\end{abstract}

received

December 15, 2016

accepted

August 11, 2017

published online

November 27, 2017
DOI https://doi.org/

10.1055/s-0037-1606622. ISSN 0100-7203.
Copyright $\odot 2017$ by Thieme Revinter

Publicações Ltda, Rio de Janeiro, Brazil
License terms

c) $(1) Ð$ 


\section{Resumo}

\author{
Palavras-Chave \\ - osteoporose \\ - climatério \\ - mandíbula \\ - radiografia \\ panorâmica \\ - menopausa
}

Conclusion The radiomorphometric indices evaluated in the mandibular panoramic radiograph are capable of identifying postmenopausal women with low mineral density in the mandible, and the results can be used to refer these women to appropriate medical investigation and/or treatment.

Objetivo Verificar o papel das radiografias maxilares panorâmicas no diagnóstico de osteoporose em mulheres na pós-menopausa.

Métodos Estudo de corte transversal, incluindo mulheres voluntárias com idade acima de 40 anos e amenorreia por falência ovariana havia pelo menos 12 meses, atendidas no ambulatório de climatério de um hospital universitário de Cuiabá-MT entre 2014 e 2015. As radiografias panorâmicas foram avaliadas por um programa de mensuração específico. Dois aspectos foram analisados na radiografia panorâmica mandibular: um qualitativo, referente à forma da cortical óssea mandibular, e outro quantitativo, referente à largura da cortical óssea mandibular. A morfologia da cortical óssea mandibular na radiografia panorâmica digital foi determinada pela observação das estruturas ósseas da região entre o forame mentoniano e a cortical óssea mandibular, bilateralmente, sendo categorizada em três grupos. O índice mentoniano (IM) foi utilizado para avaliar a espessura do córtex mandibular por meio de uma linha perpendicular à base da mandíbula na altura do centro do forame mentoniano; uma segunda linha é tangente à borda inferior da mandíbula, e uma terceira linha é tangente à superior da mandíbula. Os dados são expressos em milímetros, com um valor normal de $3,0 \mathrm{~mm}$. A densitometria da coluna lombar e do fêmur, expressa em $\mathrm{g} / \mathrm{cm}^{2}$, foi categorizada em normal, osteopenia ou osteoporose.

Resultados Observou-se boa concordância entre os resultados dos testes realizados. Quando comparado o índice mentoniano (IM) com a densitometria mineral óssea (DMO) da região lombar da coluna, o Kappa foi de 0,718 , e quando o mesmo índice foi comparado com a DMO da região do colo do fêmur, ele foi de 0,443 , demostrando boa concordância entre os dois testes. Um melhor grau concordância ocorreu quando comparados o índice da cortical óssea mandibular (ICM) com a DMO da região lombar da coluna $(0,912)$ e quando comparados o ICM e a DMO da região do fêmur 0,579 . Conclusão Os índices radiomorfométricos avaliados nas radiografias panorâmicas mandibulares mostraram ser capazes de identificar precocemente mulheres pósmenopáusicas com baixa DMO, e podem ser usados para que elas sejam encaminhadas para o tratamento/exame médico adequado.

\section{Introduction}

Osteoporosis is characterized by low bone mass and microarchitectural alterations of the bone tissue, leading to enhanced fragility and increased risk of fracture. The cortical layer of the bone becomes thinner, while the trabecular structure becomes more porous. ${ }^{1}$ Several predictors of risk of osteoporosis must be considered in the clinical practice, such as: age, body mass index, family history and hypoestrogenism. The risk of osteoporosis clearly increases after menopause. Osteoporosis is reported to occur more commonly in the lumbar spine, ranging from $15 \%$ to $38 \%$, and lower in the femoral neck, in which it ranges from $10 \%$ to $18 \%{ }^{2-4}$ Recently, mineral bone loss was reported to affect $35-52 \%$ of women aged over 50 years. ${ }^{5}$ Osteoporosis involves the whole skeleton, also affecting the mandibular bones, in which it is associated with tooth loss and failure of dental implants. ${ }^{6}$
Bone mineral density (BMD), measured by dual-energy $\mathrm{X}$ ray absorptiometry (DXA), is the standard technique for the diagnosis of osteoporosis. Regarding the oral health assistance for postmenopausal women, the dental panoramic radiograph is utilized for a variety of purposes, as part of the assessment of the status of the mandible. ${ }^{7}$ A good correlation between panoramic mandibular indices and BMD results at the femur ${ }^{8}$ and lumbar spine has been found. ${ }^{9,10}$ In fact, the association of osteoporosis in the spine and femur with bone loss in the mandible has been described over the past 50 years. ${ }^{11}$ Many studies have correlated mandibular bone mass with general skeletal bone mass, ${ }^{12,13}$ and have tried to anticipate the diagnosis of osteoporosis using panoramic radiograph indices. ${ }^{14,15}$

Currently, the exact role of the mandibular panoramic radiograph in discriminating osteoporotic women from those not affected by the condition is debatable. ${ }^{3,16}$ Since 
many postmenopausal women over 50 years of age with no previous diagnosis of osteoporosis in the spine and femur might have low skeletal bone mineral density, the mandibular status should be verified before any dental treatment to reduce complications or failures. This conduct is more important before tooth implants. The primary objective of the present study is to verify whether the panoramic radiograph presents an adequate concordance with the DXA in the diagnosis of low bone density.

\section{Methods}

\section{Patient Selection}

This cross-sectional study using accessibility sampling was conducted at a university hospital in the Brazilian Midwest, and it included 198 postmenopausal volunteers between the ages of 40 and 53 years, who were treated at a climacteric outpatient clinic between January 2014 and July 2016. The study was approved by the Ethics Committee of the institution (under CAAE 33915914.7.0000.5541). Only toothed women were included, excluding those who did not agree to sign the free and informed consent form, the users of sex steroids, thyroid hormones, corticosteroids, anticoagulants, or those using osteoporosis medications. The sample size was calculated assuming a prevalence of osteoporosis of $15 \%$ 17 and an imprecision of 5\%, using the equation $\mathrm{n}=\mathrm{Z}^{2} \times \mathrm{p}$ $(1-\mathrm{p}) /\left(\mathrm{d}^{2}\right)$.

\section{Panoramic Radiograph}

Panoramic radiographs were performed using the Kodak 8000 Digital Panoramic System (Eastman Kodak Company, Rochester, NY, US) with $2 \mathrm{~mA}, 13.9$ and $\mathrm{kV}$ ranging from 60 to 80 . The examinations were performed by the same radiologist, and the images were identified only with the initials of the names, so that no personal information was disclosed to the examiner at the time of the evaluation. Moreover, the examiner had no access to the patients' medical history and bone mineral density (BMD) results. The panoramic radiographs were evaluated using the Radio Imp (Radio Memory, Belo Horizonte, MG, Brazil) software, version 2.0. Two aspects were analyzed in the mandibular panoramic radiograph: a qualitative aspect regarding the aspect of the mandibular cortical bone, and a quantitative aspect regarding the width of the mandibular cortical bone. The measurements were taken from the right and left sides of each mandible. In the diagnosis of low mandibular bone mass, the panoramic radiograph was reported to present sensitivity and specificity of over $80 \%$ and $73 \%$ respectively. ${ }^{18}$

\section{Mandibular Cortical Index}

The mandibular cortical index (MCI, -Figs. 1A, 1B, 1C), ${ }^{19}$ is a qualitative index used to evaluate the inferior cortical bone of the mandible posterior to the mental foramen on both the left and right sides. There are three possible results. $\mathrm{C} 1=$ normal cortex: the endosteal margin of the cortex is matched and tapered on both sides; $\mathrm{C} 2$ = moderately eroded cortex: the endosteal margin shows semilunar defects resulting from lacunar resorption, or forms endosteal cortical resi-
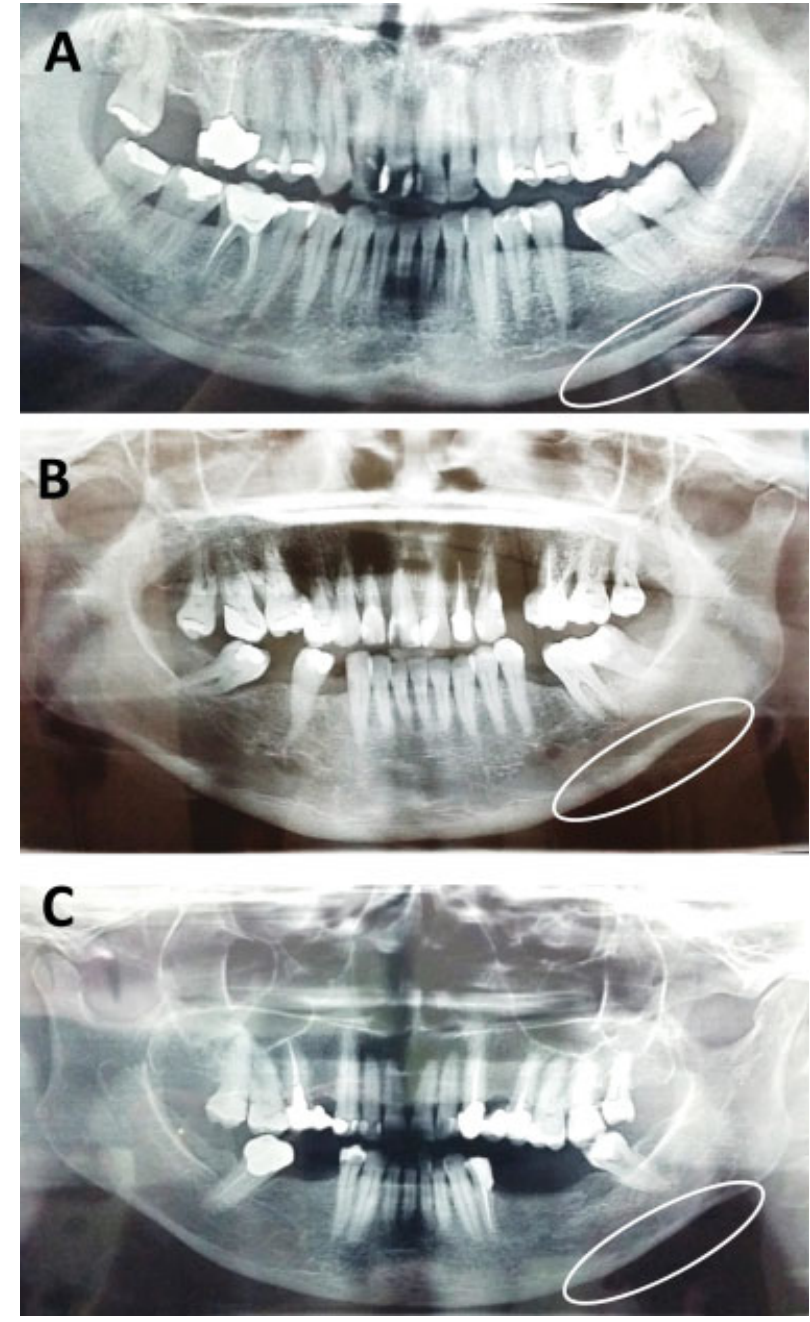

Fig. 1 Region below the foramen. C1-Panel A, smooth and regular cortical bone. C2-Panel B, semilunar defects. C3-Panel C, clearly thin cortical bone with porosity. Source: Klemetti et al (1994). ${ }^{19}$

dues; $\mathrm{C} 3$ = severely eroded or porous cortex: the cortex forms dense layers of endosteal and clearly porous cortical residues.

\section{Mental Index}

The mental index (MI, - Fig. 2) was used to evaluate the thickness of the mandibular cortical bone through a perpendicular line drawn from the base of the mandible (a) at the height of the center of the mental foramen; another line (b) is drawn tangent to the inferior border of the mandible, and a third line (c), which is parallel to the second one (b), is drawn at the superior border of the mandible. The measurement of the cortical bone thickness (mental index) is made along horizontal lines $b$ and $c$ (Ledgerton et al, 1997) ${ }^{20}$ The data are expressed in millimeters, with a normal value $\geq 3.0 \mathrm{~mm}$.

\section{Bone Mineral Density}

The individual BMD results were compared with established standards for age and sex. Despite the fact that the BMD can be measured in any part of the body, two regions (the lumbar spine and the proximal femur) were established as more 


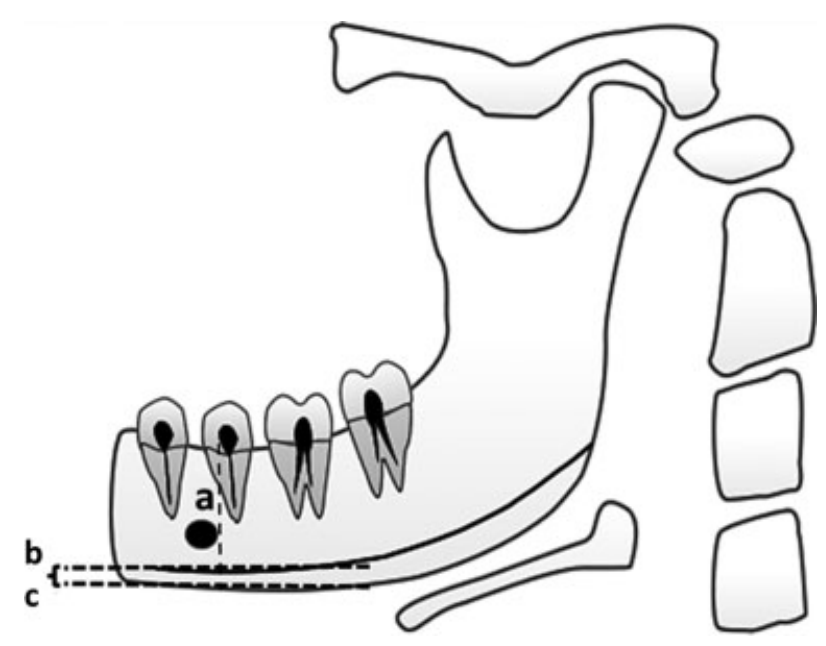

Fig. 2 Mental index. One line (B) is tangent to the lower border of the mandible, and another line is perpendicular $(A)$ to the first one, passing through the center of the mental foramen. The measurement of the cortical bone thickness (mental index) is made along the horizontal line (C). Source: the authors.

representative and important. The result is a graph with the quantification of some areas expressed in $\mathrm{g} / \mathrm{cm}^{2}$. The World Health Organization (WHO) established the diagnostic standardization criteria for the clinical use of BMD. ${ }^{20}$ Thus, BMD values below 2.5 standard deviations (SDs) from the mean peak value in young adults $(\mathrm{T} \leq-2.5)$ are compatible with the diagnosis of osteoporosis. A T-score $\leq-1$ SD indicates a healthy individual, and a T-score between $-1 \mathrm{SD}$ and -2.5 SDs identifies individuals with osteopenia.

\section{Statistical Analysis}

Data distribution was examined using the Shapiro-Wilk test, and those with Gaussian distribution are shown as the mean $(\bar{x})$ and SD. The proportions were compared using the Z-test. The agreement between the procedures was quantified using the Kappa coefficient, with a $95 \%$ confidence interval $(95 \%$ $\mathrm{CI}$ ). All statistical procedures were performed using the Statistical Package for the Social Sciences (SPSS, SPSS Inc., Chicago, IL, US) software, version 17.0. Values of $p<0.05$ were considered statistically significant.

\section{Results}

Among the women included in the study, $64.6 \%$ were white, $2.5 \%$ were black, and $32.8 \%$ were of other ethnicities. The mean age $(\bar{x})$ of the patients was $53.1 \pm 5.0$ years. $7 \%$ of the women had college degrees, but the vast majority had not finished high school, and one of them was illiterate. Total $63 \%$ were married, and none were single. Although no objective criteria were used to define the socioeconomic level, all the patients had low income.

- Table 1 shows that in the lumbar spine the BMD identified osteoporosis in 20/198 (10.1\%) patients; in the femoral neck, the condition was identified in $11 / 198$ (5.5\%) patients $(p<0.001)$. In the lumbar spine, osteopenia was diagnosed in $101 / 198$ (51\%) patients; in the femur, it was identified in
Table 1 Comparison of the absolute and relative frequencies of the bone mineral density findings in the lumbar spine and femoral neck

\begin{tabular}{|l|l|l|l|l|l|}
\hline & \multicolumn{2}{|l|}{ Lumbar spine } & \multicolumn{2}{l|}{ Femoral neck } & \\
\hline Bone mass & $\mathbf{n}$ & $\%$ & $\mathbf{N}$ & $\%$ & $\boldsymbol{p}^{*}$ \\
\hline Osteoporosis & 20 & 10.10 & 11 & 5.55 & 0.000 \\
\hline Osteopenia & 101 & 51.00 & 77 & 38.89 & 0.000 \\
\hline Normal & 77 & 38.90 & 110 & 55.56 & 0.000 \\
\hline Total & 198 & 100 & 198 & 100 & \\
\hline
\end{tabular}

Note: ${ }^{*}$ Z-test for the proportions.

$77 / 198(38.8 \%)$ patients $(p<0.001)$. The changes in bone mass of the mandible examined by panoramic radiograph were similar on the right and left sides $(p>0.05)$. Considering both sides, and using the $\mathrm{MCl}$, osteoporosis was diagnosed in approximately $9.6-10.1 \%$ of the patients, and osteopenia was diagnosed in approximately $50-54 \%$ of the patients. A mental index $>3.0 \mathrm{~mm}$ was found in $66-71 \%$ of the patients.

- Tables $\mathbf{2}$ and $\mathbf{3}$ show the degree of agreement between the mandibular radiomorphometric indices and the T-scores for the diagnosis of bone mass changes. When the mental index results were compared with the BMD findings in the lumbar spine, the agreement index was of 0.718 (95\% CI: 0.618-0817). The comparison of the results obtained with the $\mathrm{MCI}$ and the BMD in the lumbar spine showed a concordance of 0.912 (95\%Cl: 0.859-0.965). The Kappa index between the MCI and the BMD of the femoral neck was of 0.579 (95\%CI: 0.482-0.676). When the MI results were compared with the BMD results of the femoral neck, the agreement found was 0.443 (95\%CI: 0.343-0.544).

Table 2 Comparison of bone mineral density results in the lumbar spine and femoral neck with the results of the mental index for the diagnosis of osteoporosis in postmenopausal women

\begin{tabular}{|c|c|c|c|c|}
\hline \multicolumn{4}{|c|}{ Mental index } & \multirow{2}{*}{$\begin{array}{l}\text { Kappa (95\% } \\
\text { confidence } \\
\text { interval) }\end{array}$} \\
\hline BMD & Abnormal & Normal & Total & \\
\hline \multicolumn{5}{|c|}{ Lumbar spine } \\
\hline Abnormal & 121 & 00 & 121 & \\
\hline Normal & 25 & 52 & 77 & \\
\hline Total & 146 & 52 & 198 & $\begin{array}{l}0.718 \\
(0.618-0.817)\end{array}$ \\
\hline \multicolumn{5}{|c|}{ Femoral neck } \\
\hline Abnormal & 88 & 00 & 88 & \\
\hline Normal & 58 & 52 & 110 & \\
\hline Total & 146 & 52 & 198 & $\begin{array}{l}0.443 \\
(0.343-0.544)\end{array}$ \\
\hline
\end{tabular}

Abbreviation: BMD, bone mineral density. 
Table 3 Comparison of bone density results in the lumbar spine and femoral neck with the results of the mandibular cortical index for the diagnosis of osteoporosis in postmenopausal women

\begin{tabular}{|l|l|l|l|l|l|}
\hline \multirow{2}{*}{$\begin{array}{l}\text { Bone mineral } \\
\text { density }\end{array}$} & \multicolumn{4}{|l|}{ Mandibular cortical index } & $\begin{array}{l}\text { Kappa } \\
\text { (95\% confidence } \\
\text { interval) }\end{array}$ \\
\cline { 2 - 6 } & Osteoporosis & Osteopenia & Normal & Total \\
\hline Lumbar spine & 19 & 01 & 00 & 20 & \\
\hline Osteoporosis & 02 & 99 & 00 & 101 & \\
\hline Osteopenia & 00 & 07 & 70 & 77 & \\
\hline Normal & 107 & 70 & 77 & $0.912(0.859-0.965)$ \\
\hline Total & 21 & \multicolumn{5}{|l}{} \\
\hline Femoral neck & 11 & 00 & 00 & 11 & \\
\hline Osteoporosis & 68 & 00 & 77 & \\
\hline Osteopenia & 09 & 39 & 70 & 110 & \\
\hline Normal & 01 & 107 & 70 & 198 & $0.579(0.482-0.676)$ \\
\hline Total & 21 &
\end{tabular}

\section{Discussion}

The present study investigated the role of the mandibular panoramic radiograph in the identification of mandibular bone mass in Brazilian postmenopausal women. In addition, the results obtained with the panoramic radiograph were compared with those obtained using DXA in the lumbar spine and femoral neck. The degrees of agreement between the two tools are provided. Using DXA, the prevalence of osteoporosis was twice higher in the lumbar spine than in the femoral neck. Using the panoramic radiograph, the prevalence of abnormal MCIs was similar to the results found with DXA in the lumbar spine. However, abnormal MIs were found in $\sim 70 \%$ of postmenopausal women. The panoramic radiograph showed similar results in the right and left sides of the mandible. Regarding the BMD findings, the panoramic radiograph and the DXA demonstrated a moderate to good agreement, mainly when the results of the mandibular panoramic radiograph were compared with the DXA in the lumbar spine.

Even though DXA is the standard procedure to measure general bone mass and its results are predictive of the risk of fracture, the procedure is limited to a small part of the population, and whether its results could also be expanded to the mandible is debatable. Dental panoramic radiographs are frequently taken for the examination of the mandibles in the general dental practice. It is possible that osteoporotic women are accurately identified using the status of the mandibular inferior cortex as a criteria to expand the investigation. ${ }^{10}$ The patients' age should be taken into consideration when osteoporosis is diagnosed using the panoramic radiograph; therefore, in early postmenopausal women, this procedure might not detect small changes in the mandibular microarchitecture.

For over 50 years, the efficiency of the panoramic radiograph in identifying mandibular osteoporosis was shown in different populations, $2,10,11,21,22$ and the current results confirm previous findings in early postmenopausal Brazilian women. ${ }^{8}$ In the dental practice, a cortical bone width $\geq 3$ $4 \mathrm{~mm}$ seems not to be an appropriate threshold for referral

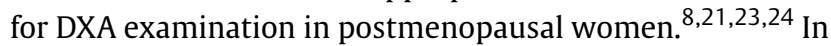
addition, it was shown that a $1-\mathrm{mm}$ decrease in cortical bone width increases the likelihood of low BMD to $40 \%$ using DXA. ${ }^{24}$ The MI has shown a long-term positive correlation with skeletal bone loss and tooth loss, ${ }^{10,23}$ but it has presented inconsistent sensitivity. Regarding the cortical bone width (MI), $90 \%$ of the patients with width $<3 \mathrm{~mm}$ may present low BMD, and $30 \%$ of them have osteoporosis. ${ }^{3}$ Using this criterion, in the present study, the mandibular cortical bone width suffered a $30 \%$ decrease in young postmenopausal women, corroborating similar results found in another study including Caucasian women. ${ }^{23}$

Using the $\mathrm{MCI}$, osteoporosis was diagnosed in $10 \%$ of the patients, and osteopenia, in $50 \%$ of the patients in the current study. A similar prevalence was found for the lumbar spine using DXA. Several studies have shown that postmenopausal women with eroded mandibular cortical bones have elevated bone resorption and are more likely to present low BMD in the DXA evaluation. ${ }^{3-5}$ The correlation between the panoramic radiograph and DXA has been examined by other authors, but the results are inconsistent. ${ }^{5,25,26}$ An early study found a poor correlation between these tools, ${ }^{13}$ but other studies found that the mandibular cortical bone mass is wellcorrelated with the overall skeletal body mass. ${ }^{12,27,28}$

Too little data are available regarding the degree of agreement between the dental panoramic radiograph and the skeletal DXA in the identification of low BMD in postmenopausal women. Even though both methods present a moderate to good sensitivity, they have never been used as interchangeable tools., ${ }^{3,23}$ In the present study, the MCI presented an excellent and significant agreement with the DXA at the lumbar spine, and a moderate agreement with the DXA at the femoral neck. The MI and DXA showed a moderate and poor agreement at the lumbar spine and femoral neck 
respectively. These results are consistent and even better than those found in another study with postmenopausal Brazilian women. ${ }^{12,28}$

A few limitations must be considered in the present study: the women included in it were not healthy volunteers from the community, but subjects recruited from an outpatient tertiary academic menopause clinic. The cut-off threshold of cortical bone width of $3 \mathrm{~mm}$ might not be as appropriate for multi-ethnic young Brazilian postmenopausal women as it was for Asian, Greek and Caucasian ethnicities. ${ }^{23}$ As strengths, the current study used the two mandibular indices that have previously demonstrated high reproducibility and good association with DXA T-scores. ${ }^{21,29-32}$

\section{Conclusion}

The prevalence rates of osteoporosis found in the lumbar spine and femoral neck in the present study are consistent with other reports on early postmenopausal women. There were moderate to excellent agreements between the mandibular panoramic radiograph and the DXA findings in the lumbar spine and femoral neck regarding BMD. The results of the current study demonstrated that the panoramic radiograph can be used in young postmenopausal women as a tool to diagnose precocious loss of mandibular cortical bone density, and to give support for dental treatment. In addition, it serves as an instrument for the referral of those patients to a specialist for a specific examination, definitive diagnosis, and possibly an early and adequate treatment of the disease.

\section{References}

1 Parfitt AM, Mathews CH, Villanueva AR, Kleerekoper M, Frame B, Rao DS. Relationships between surface, volume, and thickness of iliac trabecular bone in aging and in osteoporosis. Implications for the microanatomic and cellular mechanisms of bone loss. J Clin Invest 1983;72(04):1396-1409. Doi: 10.1172/JCI111096

2 Iki M, Kagamimori S, Kagawa Y, Matsuzaki T, Yoneshima H, Marumo F. Bone mineral density of the spine, hip and distal forearm in representative samples of the Japanese female population: Japanese Population-Based Osteoporosis (JPOS) Study. Osteoporos Int 2001;12(07):529-537. Doi: 10.1007/s001980170073

3 Taguchi A, Tsuda M, Ohtsuka M, et al. Use of dental panoramic radiographs in identifying younger postmenopausal women with osteoporosis. Osteoporos Int 2006;17(03):387-394. Doi: 10.1007/ s00198-005-2029-7

4 Vlasiadis KZ, Skouteris CA, Velegrakis GA, et al. Mandibular radiomorphometric measurements as indicators of possible osteoporosis in postmenopausal women. Maturitas 2007;58(03): 226-235. Doi: 10.1016/j.maturitas.2007.08.014

5 Passos JS, Gomes Filho IS, Sarmento VA, et al. Women with low bone mineral density and dental panoramic radiography. Menopause 2012;19(06):704-709. Doi: 10.1097/gme.0b013e318240f938

6 von Wowern N. General and oral aspects of osteoporosis: a review. Clin Oral Investig 2001;5(02):71-82. Doi: 10.1007/s007840100105

7 Graham S, Hammond-Jones D, Gamie Z, Polyzois I, Tsiridis E, Tsiridis E. The effect of beta-blockers on bone metabolism as potential drugs under investigation for osteoporosis and fracture healing. Expert Opin Investig Drugs 2008;17(09):1281-1299. Doi: $10.1517 / 13543784.17 .9 .1281$

8 White SC, Taguchi A, Kao D, et al. Clinical and panoramic predictors of femur bone mineral density. Osteoporos Int 2005; 16(03):339-346. Doi: 10.1007/s00198-004-1692-4
9 Bodade PR, Mody RN. Panoramic radiography for screening postmenopausal osteoporosis in India: a pilot study. Oral Health Dent Manag 2013;12(02):65-72

10 Taguchi A, Suei Y, Ohtsuka M, Otani K, Tanimoto K, Ohtaki M. Usefulness of panoramic radiography in the diagnosis of postmenopausal osteoporosis in women. Width and morphology of inferior cortex of the mandible. Dentomaxillofac Radiol 1996;25 (05):263-267. Doi: 10.1259/dmfr.25.5.9161180

11 Groen JJ, Duyvensz F, Halsted JA. Diffuse alveolar atrophy of the jaw (non-inflammatory form of paradental disease) and presenile osteoporosis. Gerontol Clin (Basel) 1960;2:68-86

12 Kribbs PJ, Chesnut CH III, Ott SM, Kilcoyne RF. Relationships between mandibular and skeletal bone in an osteoporotic population. J Prosthet Dent 1989;62(06):703-707. Doi: 10.1016/00223913(89)90596-9

13 Klemetti E, Kolmakov S, Heiskanen P, Vainio P, Lassila V. Panoramic mandibular index and bone mineral densities in postmenopausal women. Oral Surg Oral Med Oral Pathol 1993;75(06): 774-779. Doi: 10.1016/0030-4220(93)90438-A

14 Kribbs PJ. Comparison of mandibular bone in normal and osteoporotic women. J Prosthet Dent 1990;63(02):218-222. Doi: 10.1016/0022-3913(90)90108-0

15 Taguchi A, Tanimoto K, Suei Y, et al. The estimation of the radiomorphometric indices of the mandible using panoramic radiograph. Dent Radiol 1993;33:309-316. Doi: 10.11242/ dentalradiology1960.33.309

16 Mohajery M, Brooks SL. Oral radiographs in the detection of early signs of osteoporosis. Oral Surg Oral Med Oral Pathol 1992;73 (01):112-117. Doi: 10.1016/0030-4220(92)90167-O

17 Pinheiro MM, Ciconelli RM, Martini LA, Ferraz MB. Clinical risk factors for osteoporotic fractures in Brazilian women and men: the Brazilian Osteoporosis Study (BRAZOS). Osteoporos Int 2009; 20(03):399-408. Doi: 10.1007/s00198-008-0680-5

18 Calciolari E, Donos N, Park JC, Petrie A, Mardas N. Panoramic measures for oral bone mass in detecting osteoporosis: a systematic review and meta-analysis. J Dent Res 2015;94(3, Suppl) 17S-27S. Doi: 10.1177/0022034514554949

19 Klemetti E, Kolmakov S, Kröger H. Pantomography in assessment of the osteoporosis risk group. Scand J Dent Res 1994;102(01): 68-72. Doi: 10.1111/j.1600-0722.1994.tb01156.x

20 Ledgerton D, Horner K, Devlin H, Worthington H. Panoramic mandibular index as a radiomorphometric tool: an assessment of precision. Dentomaxillofac Radiol 1997;26(02):95-100. Doi: 10.1038/sj.dmfr.4600215

21 World Health Organization. Assessment of fracture risk and its application to screening for postmenopausal osteoporosis. Report of a WHO Study Group. World Health Organ Tech Rep Ser 1994; 843:1-129

22 Ross PD, Fujiwara S, Huang C, et al. Vertebral fracture prevalence in women in Hiroshima compared to Caucasians or Japanese in the US. Int J Epidemiol 1995;24(06):1171-1177. Doi: 10.1093/ije/ 24.6.1171

23 Devlin H, Horner K. Mandibular radiomorphometric indices in the diagnosis of reduced skeletal bone mineral density. Osteoporos Int 2002;13(05):373-378. Doi: 10.1007/s001980200042

24 Nakamoto T, Taguchi A, Ohtsuka M, et al. Dental panoramic radiograph as a tool to detect postmenopausal women with low bone mineral density: untrained general dental practitioners' diagnostic performance. Osteoporos Int 2003;14(08):659-664. Doi: 10.1007/s00198-003-1419-y

25 Law AN, Bollen AM, Chen SK. Detecting osteoporosis using dental radiographs: a comparison of four methods. J Am Dent Assoc 1996;127(12):1734-1742. Doi: 10.14219/jada. archive.1996.0134

26 Taguchi A, Sanada M, Krall E, et al. Relationship between dental panoramic radiographic findings and biochemical markers of bone turnover. J Bone Miner Res 2003;18(09):1689-1694. Doi: 10.1359/jbmr.2003.18.9.1689 
27 Lee K, Taguchi A, Ishii K, et al. Visual assessment of the mandibular cortex on panoramic radiographs to identify postmenopausal women with low bone mineral densities. Oral Surg Oral Med Oral Pathol Oral Radiol Endod 2005;100(02):226-231. Doi: 10.1016/j.tripleo.2004.11.052

28 Horner K, Devlin H, Alsop CW, Hodgkinson IM, Adams JE. Mandibular bone mineral density as a predictor of skeletal osteoporosis. Br J Radiol 1996;69(827):1019-1025. Doi: 10.1259/00071285-69-827-1019

29 Ito M, Hayashi K, Kawahara Y, Uetani M, Imaizumi Y. The relationship of trabecular and cortical bone mineral density to spinal fractures. Invest Radiol 1993;28(07):573-580
30 Jonasson G, Bankvall G, Kiliaridis S. Estimation of skeletal bone mineral density by means of the trabecular pattern of the alveolar bone, its interdental thickness, and the bone mass of the mandible. Oral Surg Oral Med Oral Pathol Oral Radiol Endod 2001;92 (03):346-352. Doi: 10.1067/moe.2001.116494

31 Jeffcoat MK, Lewis CE, Reddy MS, Wang CY, Redford M. Post-menopausal bone loss and its relationship to oral bone loss. Periodontol 2000 2000;23:94-102. Doi: 10.1034/j.1600-0757.2000.2230109.x

32 Benson BW, Prihoda TJ, Glass BJ. Variations in adult cortical bone mass as measured by a panoramic mandibular index. Oral Surg Oral Med Oral Pathol 1991;71(03):349-356. Doi: 10.1016/00304220(91)90314-3 